\title{
THE ANCIENT AND MODERN MANO CORNUTA USE
}

O USO ANTIGO E MODERNO DE MANO CORNUTA

Maria Mertzani

Como citar este artigo:

MERTZANI, Maria The ancient and modern mano cornuta use. In: Cadernos do Lepaarq, v. XV, n.30., p. 19-37, JulDez. 2018. 


\title{
The ancient and modern mano cornuta use
}

\author{
Maria Mertzani*
}

\begin{abstract}
The study analyses the iconography of 602 Attic vases where the mano cornuta appears, and parallels its themes to the meanings of $110 \mathrm{Y}$-handshape signs of three sign languages: the American Sign Language, Brasilian Sign Language, and Greek Sign Language. The examination demonstrates mano cornuta to be the etymon of cognate signs among the three sign languages.
\end{abstract}

Resumo: O estudo analisa a iconografia de 602 vasos áticos, onde aparece a mano cornuta, e paraleliza seus temas com os significados de 110 sinais com a configuração de mão Y, em três línguas de sinais: em Língua de Sinais Americana, em Língua de Sinais Brasileira e em Língua de Sinais Grega. O exame demonstra que a mano cornuta é o étimo dos sinais cognatos entre as três línguas de sinais.

\section{Keywords:}

Mano cornuta; American Sign Language; Greek Sign Language; Brasilian Sign Language; Attic vase iconography.

\section{Palavras-Chave:}

Mano cornuta; Língua de Sinais Americana; Língua de Sinais Grega; Língua de Sinais Brasileira; Iconografia de vasos áticos.

* Instituto de Educação, Universidade Federal do Rio Grande (FURG), Brasil; Professora Visitante. Email: maria.d.mertzani@gmail.com 


\section{INTRODUCTION}

As a work in progress, the study has analysed the iconography of 602 Attic vases $^{l}$ from the online Corpus Vasorum Antiquorum (CVA, 2004), from which 1,32\% $(\mathrm{n}=8)$ only involves the mano cornuta (the horned hand) (Table 1). The themes of this iconography were then paralleled to the meanings of $110 \mathrm{Y}$-handshape ${ }^{2}$ signs with the scope to investigate the historic relatedness of three sign languages (SLs) with the mano cornuta: of the American Sign Language - ASL ( $n=36$ ); Greek Sign Language - GSL $(n=28)$; and Brasilian Sign Language - LIBRAS $(n=46)$. By examining the meanings and the iconicity of the specific handshape, the study demonstrates the derivation and formation of certain signs from the mano cornuta, and their cross-cultural correspondence in these SLs.

The starting point of this comparison stands the work by Shaw and Delaporte (2015), who etymologised certain ASL signs on their cognates in French Sign Language (LSF), which, subsequently, connect to the mano cornuta. In line with this, and considering the fact that LSF is a Mediterranean SL, the study wanted to show such association with another Mediterranean SL like GSL, which according to historic records (e.g. Plato, Cratylus) is older than any known SL in the specific area. In addition, the mano cornuta was broadly used in ancient, and is still in use in contemporary Greece.

Table 1: The mano cornuta in the Attic vases

\begin{tabular}{|c|c|c|c|c|}
\hline CVA Vase Record Number* & H-handshape & Y-handshape & Date BCE & Museums \& Collections \\
\hline 20 (BAPD: 211990) & $\mathrm{x}$ & & $475-425$ & $\begin{array}{l}\text { VIENNA, Kunsthistorisches Museum } \\
\text { i (AUSTRIA 1, pls. } 1 \text { - 50) }\end{array}$ \\
\hline 41 (BAPD: 12084) & & $\mathrm{x}$ & $425-375$ & $\begin{array}{l}\text { VIENNA, Kunsthistorisches Museum } \\
\text { i (AUSTRIA 1, pls. } 1 \text { - 50) }\end{array}$ \\
\hline 75 (BAPD: 340004) & $\mathrm{x}$ & & $450-400$ & $\begin{array}{l}\text { VIENNA, Kunsthistorisches Museum } \\
\text { ii (AUSTRIA 2, pls. } 51-100 \text { ) }\end{array}$ \\
\hline 131 (BAPD: 218091, 218105) & $\mathrm{x}$ & $\mathrm{x}$ & $400-300$ & $\begin{array}{l}\text { VIENNA, Kunsthistorisches Museum } \\
\text { iii (AUSTRIA 3, pls. } 101 \text { - 150) }\end{array}$ \\
\hline 132 (BAPD: 568) & $\mathrm{x}$ & & $400-300$ & $\begin{array}{l}\text { VIENNA, Kunsthistorisches Museum } \\
\text { iii (AUSTRIA 3, pls. } 101 \text { - 150) }\end{array}$ \\
\hline 83 (BAPD: no matching record) & & $\mathrm{x}$ & NA & $\begin{array}{l}\text { BRUSSELS, Musées Royaux d'Art } \\
\text { et d'Histoire ii (BELGIUM 2, pls. } \\
49 \text { - 96) }\end{array}$ \\
\hline 75 (BAPD: no matching record) & $\mathrm{x}$ & & NA & $\begin{array}{l}\text { BRUSSELS, Musées Royaux d'Art } \\
\text { et d'Histoire ii (BELGIUM 2, pls. } \\
49 \text { - 96) }\end{array}$ \\
\hline TOTAL: & 5 & 3 & & \\
\hline
\end{tabular}

The small appearance of the mano cornuta in Attic iconography agrees with the fact that the Y-handshape is known as a marked handshape as it does not occur frequently ${ }^{3}$ in most SLs (cf. KOOIJ \& CRASBORN, 2016). The SL sample is based on the following dictionaries: for ASL, on the American Sign Language handshape dictionary by Tennant and Gluszak Brown (1998), and on The Gallaudet dictionary of American Sign Language by Valli (2005); for GSL, on the Online Dictionary of Concepts in GSL by the Educational Policy Institute (2013), and the Dictionary of Sign Language by Magganaris

$1 \quad$ CVA vase photos are copyrighted. The reader can access them online using the record numbers in Table 1.

2 The naming of the handshapes follows the fingerspelled forms of SLs. Thus, the Y-handshape is the form for the Y letter, and the H-handshape for the $\mathrm{H}$ letter. The latter is an alternative handshape of the $\mathrm{Y}$-handshape.

3 For example, $\mathrm{n}=51$ signs were met, representing a $2,6 \%$ only out of a total $\mathrm{N}=1927$ LIBRAS signs. 
(1998); and for LIBRAS, on the online Dicionário da Lingua Brasileira de Sinais V3 by Azambuja Lira and Souza (2011).

To date, there is no documented evidence that proves the connection of GSL with ASL and LSF, although due to the frequent contact among deaf people (e.g. in international conferences), there are traces of ASL sign transmission to GSL. Additionally, LIBRAS is chosen as a historically cognate SL to ASL and LSF, therefore a considerable number of cognate signing was expected to be etymologised on both SLs. Furthermore, this study records systematically and for the first time archaeological indexes of the mano cornuta in ancient Greece (in Attic vase), which, in turn, demonstrate etymological association with the Y-handshape signs of the three SLs.

\section{MANO CORNUTA IN ANTIQUITY}

One of the earliest examples comes from the sixth Egyptian Dynasty in the Qar tomb (SIMPSON, 1976; ROTH, 1993), where various scenes show the performance of the mano cornuta by the followers and/or suppliants of the departed as a gesture of honour, and/or a worship act for the Egyptian sun Ra. In relation to the sun, its Y-handshape form is clearly performed in front of the sun disk, which, in turn, was usually depicted over the head of a cow. This solar relationship is also supported by another iconography where $\mathrm{Ra}$, as a young boy, performs the mano cornuta in the centre of a circle that was formed by the serpent ouroboros (BIEDERMANN, 1989, p. 362). Elsewhere (WILKINSON, 1994, p. 259), the specific handshape is performed in front of a vase, an imagistic motif that is preserved in Greek archaic and classical times. During Bronze Age (ca. 1303 BCE), the mano cornuta is articulated in the battlefield, sometimes by captives in front of the king, as they are trying to protect themselves against the king's subjugation (PANAITE, 2014).

In Egyptian, Minoan and Mycenaean civilisations the cow and/or the bull symbolised the sun, with which the mano cornuta was associated. This relationship is demonstrated on a Greek kylix from the middle of the sixth century BCE (HARRISON, 1908, p. 407), where god Dionysus holds aloft his characteristic wine-cup (the kantharos), and the goddess Semele (a moon goddess) performs the mano cornuta in front of his face (Figure 1). Dionysus was the son of Zeus, and therefore he

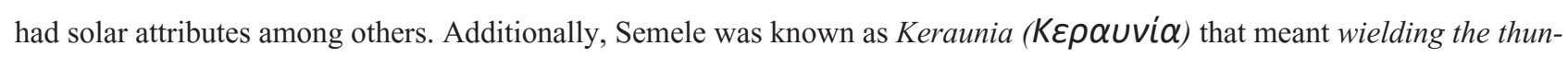

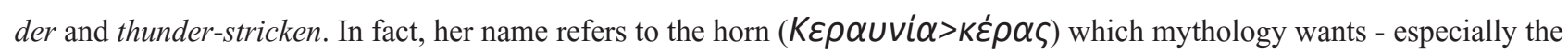
horns of a cow with which the mano cornuta is always associated (cf. KING, 1949) - to become thunderbolts (GUBERNATIS, 1872, p. 107).

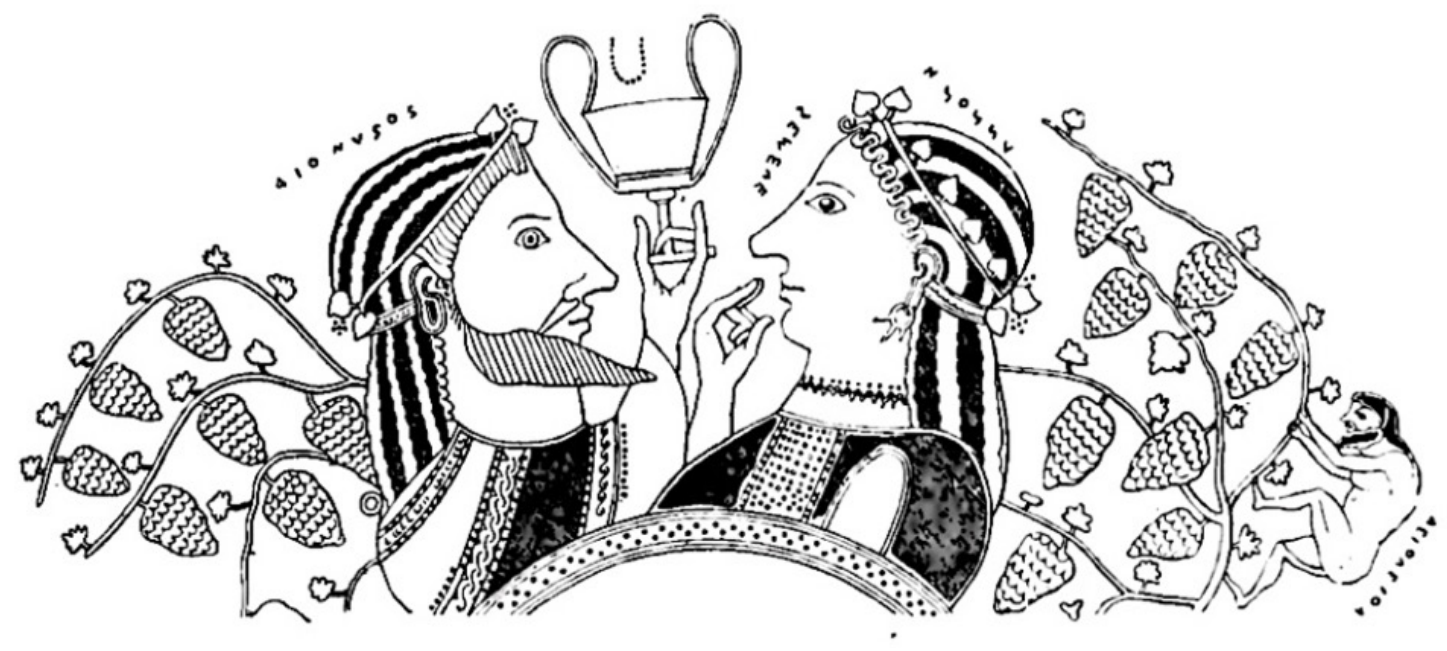

Figure 1: Semele performing mano cornuta in front of Dionysus. 
Since the mano cornuta appears next to vessels, it is most probably linked to an archetypal fertility worship, that of the Mother Goddess. In this, the vessel represented the rain season between the equinoxes, and the womb of the Mother Goddess (COHEN, 1993; MACGILLIVRAY, 2004; MAGINI, 2015; ŠrRAJC, 1993), who was usually depicted by the moon's sickle shape (as the new moon) and/or by the cow's horns (cf. MERTZANI, 2017). In particular, the moon, as the lunar sun (GRAULICH, CARRASCO, COE, DURAND-FOREST, et al., 1981; HEALEY, 1977), referred to the fertility of the earth and women during the rain period of the agricultural cycle (cf. GREEN, 2014; MILBRATH, 1999), during which the onset and end of the rains coincides with the extremes of Venus that also formed an extension to the moon's and sun's symbolism (as an evening and morning star) (MAGINI, 2015, p. 29-30; ŠPRAJC, 1993, p. 42). Due to this association, the mano cornuta represented Venus as well, especially its sickle appearance between the earth and the sun.

Metonymically then, as a solar and lunar symbol, the mano cornuta represented day and night, life and death, a relationship which explains its depiction in tombs. For example, in the Etruscan tomb of the Lionesses at Tarquinia (ca. 520 $\mathrm{BCE}$ ), a figure dances and acts the H-handshape mano cornuta (with the right hand), most probably as a radiating solar energy against evil, and hence, as a benevolent act in afterlife (HOLLOWAY, 1986, p. 448-449; MORRIS, 1979, p. 128). Much later, in early Church iconography of the tenth century, the mano cornuta is clearly illustrated as the sun's rays with beneficial energy (ELWORTHY, 1900, p. 157).

Currently, in the Mediterranean, the mano cornuta under its H-handshape form only is still in use as a common gesture strictly in Greece, Italy, Portugal, and Spain. In Malta, it is used in types of horned amulets, such as the qrun (the horn)

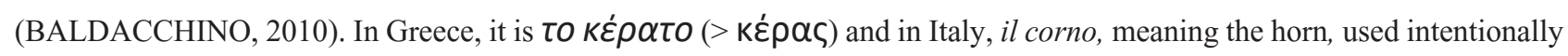
(while uttering the specific words) for prophylactic purposes. By wearing it and/or acting it, people believe to be protected by the evil eye that is regarded to cause "dryness" under the form of barrenness and the inability to bear children (KRIPPNER, BUDDEN, GALLANTE \& BOVA, 2011). It also signifies horn-related metaphors concerning betrayal or emasculated lover, leaving phallic connotations as well. These latter meanings come from medieval years, when the mano cornuta was associated with fools and cuckolds (SALE, 2016; SHAW \& DELAPORTE, 2015). In France and the northern European countries (e.g. the Netherlands, Belgium, Austria) it is extinct and/or is extremely rare (cf. MORRIS, 1994).

\section{ANALOGIES TO THE MANO CORNUTA}

Apart from the Mediterranean, and similar to the mano cornuta, the Y-handshape and H-handshape forms are recorded in Oceania, Australia, India and South America as traditional signs. Beginning with India, the specific signs appear in traditional dance hand movements (cf. CAROLL \& CAROLL, 2013) denoting: female characters with a bow/arrow, female energy and love; a huntress goddess; and various animals like tortoise, deer, and antelope (Figure 2). The deer and goddess are also denoted through the Y-handshape that also expresses the female reproductive organs among other meanings (house, body, ground, etc.). This handshape used to mean wife in the union of male and female, which, in turn, is denoted by the H-handshape that also means fertility, cattle, wind and/or storm, and the instruments drum and/or flute. Under the meaning of wild animals, the H-handshape represents the lion. The majority of these meanings connect to the aforementioned symbolism of the mano cornuta, especially to its representation of horned animals, solar animals (the lion), femininity, female organs, and of a goddess. 


\section{a. \\ bow \\ Dhanu Mudra

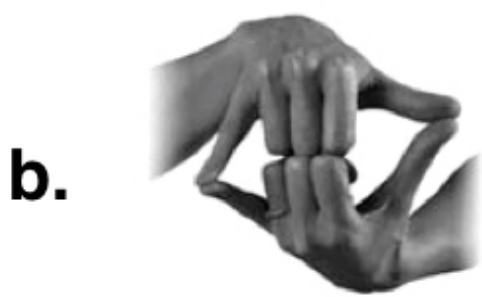 \\ tortoise Kurma Mudra II}

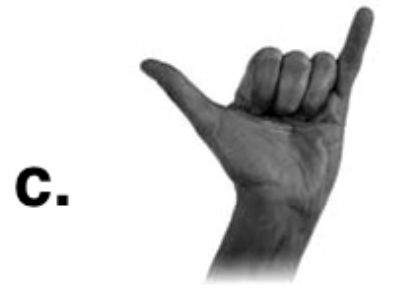

deer/wild animals

Mushtimriga Mudra

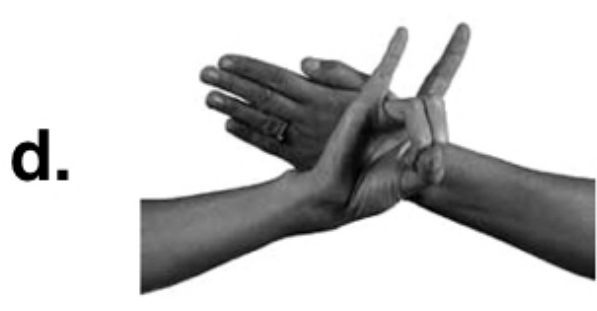

lion Simha Mudra

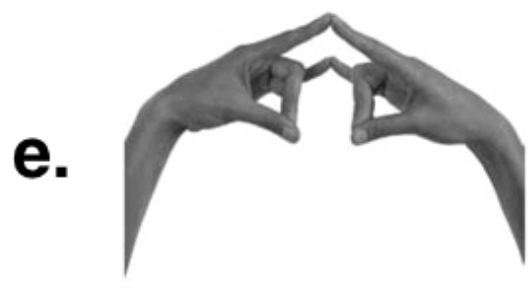

to bind

Bam Mudra

Figure 2: Examples of Indian traditional dance hand movements.

In Walmajarri peoples of Australia, the Y-handshape is used for the sign KUNGA that means 'woman' and 'morning' (BIEUNDURRY, 2007), hence connecting again the handshape with femininity, the day light, and a velar word, as it is shown

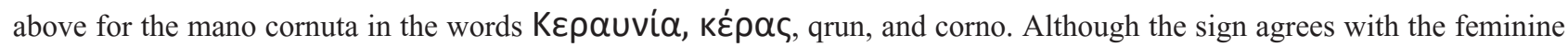
symbolism of the mano cornuta, it is difficult to support the pre-existence of cows in far antiquity in Australia and kunga to symbolise a cow. However, other signs from Australian aboriginals (e.g. Ngada) suggest the Y-handshape to refer to the animal wallaby (MOUNTFORD, 1938, p. 154), which in rituals represents the eternal man Kugu'uthu (WILLIAMS, 2000, p. 355), the fire generator (ROSSOTTI, 2002, p. 239).

In Brasil, the Y-handshape is broadly used as a salutation ${ }^{4}$ sign, likewise the shaka ${ }^{5}$ sign for the Hawaiian $a l o h a^{6}$, which is a greeting of love, gratitude and affection. Interestingly, aloha derivatives (e.g. alohi, alohikea) mean 'to shine, to sparkle, to glitter,' 'brightness,' and 'white light' (ANDREWS, 1922, p. 52), linking again the Y-handshape to sunlight meanings.

$4 \quad$ In Umbanda and Candomblé rituals, the Y-handshape and H-handshape are used as worship salutation signs. To the best of my knowledge, the meanings of these signs are not yet examined in this ritualistic context.

5 Morris (1994, p. 218) supported the origin of shaka in a modified version of a Spanish drinking gesture. However, historic linguistics of Spanish Sign Language demonstrates that, where the specific drinking sign changes (PARKHURST \& PARKHURST, 2003, p. 4), it is always articulated close to the mouth and not away from it. Additionally, in other SLs, the change always refers to the modification of the handshape and not to the location of the sign's articulation.

$6 \quad$ Aloha (and alohi) involves words referring to the face, front, and an upper surface (alo); the number two (e.g. as two people making love) $(a l u)$; the blue or bluish colour $(h a)$, and the flowing water and/or the sea $(h i)$. This first compound of aloha, involves the word $a$ ' $a$ (light, glowing) as in a'alo and alo. Cf. ali' $i$ (chiefs, king queen, etc.), alaula (light of early dawn, sunset light), 'alua (two, twice), and 'alima (five, five times). In this latter, $m a$ is a preposition meaning 'at, in, on', and 'and other(s)' (PUKUI, ELBERT, MOOKINI, 1992, p. 3, 10, 11, 87). 


\section{RESULTS}

\section{The mano cornuta in the Attic vases}

So far, the iconography of the Attic vases shows that the mano cornuta was more frequently depicted with masculine figures (e.g. youth, satyrs) dancing next to a vessel (e.g. vase no. 20), reminding thus the aforementioned fertility symbolism. There is one incidence only (vase no. 83) in which the mano cornuta is performed by a female figure on the right side of a satyr and in front of a dionysian drum, bearing thus a solar meaning that is connoted by the drum itself (cf. DI GIULIO, 1991) and the horns over it. This solar symbolism is also met in vase no. 132, where Dionysus (as a solar god) sits performing the mano cornuta, and his maenads are also articulating it.

Table 2: The articulation of the mano cornuta

\begin{tabular}{|c|c|c|c|}
\hline CVA Vase & Mano Cornuta & Location & Comments \\
\hline 20 & H-handshape & Upper right & $\begin{array}{l}\text { Man, right hand, on the level of the eye; } \\
\text { tongue protrudes. }\end{array}$ \\
\hline 41 & Y-handshape & Left up & Satyr, left hand, on the level of the shoulder. \\
\hline 75 & H-handshape & Right down & $\begin{array}{l}\text { Young man, right hand, on the level of the } \\
\text { waist. }\end{array}$ \\
\hline 131 & $\begin{array}{l}\text { H-handshape \& } \\
\text { Y-handshape }\end{array}$ & $\begin{array}{l}\text { H-handshape: } \\
\text { Gaia: right had - upper left; left hand- } \\
\text { down. } \\
\text { Apollo: left hand - down. } \\
\text { Hermes: right hand - upper right. } \\
\text { Goddess Hera(?): left hand-upper left. } \\
\text { Y-handshape: } \\
\text { Zeus: right hand - right up. } \\
\text { Heracles: right hand - centre down. } \\
\text { Two athletes: left hand-left up. } \\
\text { One athlete: right hand-right up. }\end{array}$ & $\begin{array}{l}\text { Only Zeus's sign is directed to Gaia and } \\
\text { the swan. Apollo's is directed downwards; } \\
\text { Heracles's to the four horses; and of the } \\
\text { remaining gods, the handshape is turned } \\
\text { to the eye. Gaia does not look at her right } \\
\text { handshape. } \\
\text { Two athletes look at each other, and sign the } \\
\text { mano cornuta over a short column; the third } \\
\text { athlete is facing them, performing the mano } \\
\text { cornuta with his right hand, over the higher } \\
\text { column. }\end{array}$ \\
\hline 132 & H-handshape & $\begin{array}{l}\text { Dionysus: right hand-right up. } \\
\text { Maenad behind Dionysus: right hand } \\
\text { - right up. } \\
\text { Maenad/Priestess in front of Dionysus: } \\
\text { left hand-left up. } \\
\text { Man (suppliant?): right hand - right } \\
\text { up. }\end{array}$ & $\begin{array}{l}\text { The mano cornuta is performed on the level } \\
\text { of the chest. }\end{array}$ \\
\hline 83 & Y-handshape & Maenad (?): left hand-upper left. & $\begin{array}{l}\text { The mano cornuta is performed over her } \\
\text { head. }\end{array}$ \\
\hline 75 & H-handshape & Right hand - lower right. & $\begin{array}{l}\text { Young man, the mano cornuta downwards, } \\
\text { on the level of the waist. }\end{array}$ \\
\hline
\end{tabular}

In vase no. 131, the mano cornuta is performed by the Greek gods Zeus, Gaia ( $\Gamma \alpha \tilde{\alpha} \alpha)$, Apollo, and Hermes. In particular, its performance by the central goddess who holds the swan (by both hands), signifies its relation to the axis of the earth.

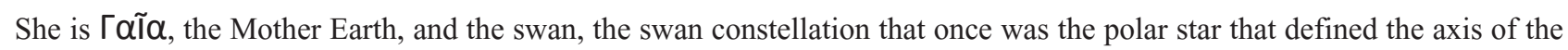
earth (MAGLI, 2009, p. 179). In fact, the swan and the mano cornuta is depicted just over the omphalus, a scene recalling the Delphic omphalus on which her name is attested. This relationship is also met in the scene with the athletes, who perform the mano cornuta over columns that were also symbols of the earth's axis and phallus (BUSENBARK, 1949, p. 162). Furthermore, in one of these scenes, Heracles is depicted to perform the mano cornuta by his right hand, while holding with his left 
a sphere in front of four horses (as solar symbols too).

In vase no. 75 (BAPD: 202619), the mano cornuta in its H-handshape form is performed by a male youth with his right hand in front of a hare that stood for the spring equinox in the sign of Taurus (RICHER, 1994, p. 138), an association that also confirms its relation to the bull as the Taurus constellation used to represent.

As Table 2 shows, the mano cornuta is performed more frequently on the level of the shoulders and/or higher (on the level of the eye or over the head), an articulation that agrees with its traditional performance (MORRIS, 1979, p. 136), as well as with traditional Y-handshape signs in Australia, Brasil and Oceania.

\section{The mano cornuta in the three SLs}

Table 3 displays the number of signs that relate to the mano cornuta. As it was expected, GSL maintains it more than the ASL and LIBRAS, where its appearance is quite similar. Overall, it maintains its ancient symbolism denoting the cow, calf, ox, and the bull. For example, the ASL BULL is based on the H-handshape form performed on one's forehead alike the mano cornuta (p. 133).

Table 3: The mano cornuta in ASL, GSL and LIBRAS

\begin{tabular}{|l|l|l|l|}
\hline & ASL & GSL & LIBRAS \\
\hline Mano cornuta & $10 / 36$ & $14 / 28$ & $14 / 46$ \\
& $(28 \%)$ & $(50 \%)$ & $(30 \%)$ \\
\hline
\end{tabular}

The three SLs converge in the signs PLAY, CELEBrATE, ANNIVERSARY, and WALK/ENTERTAINMENT (Figure 3). Their similar handshape and movement indicates common ancestry that can be traced in the worship of the Mother Goddess and her sistrum instrument. The articulation of the sign appears to imitate the holding of the sistrum - which also symbolised the head of a cow - in a similar fashion to the ASL CELEBRATE. Shaw and Delaporte (2015, p. 203) justify the Y-handshape as representing the letter $<\mathrm{J}>$ from the French verb jouer, which is also etymologised on the AG í $\dot{\omega}$ (jouer $>$ Latin, iocare, iocus $>$ AG, $\dot{\eta}$ iupri: a shout of joy or pain > í́, exclamation of joy or sorrow) that meant the Io cow goddess and the moon. This etymology also justifies the GSL WALK/ENTERTAINMENT and LIBRAS BIRTHDAY/ANNIVERSARY, since jouer also recalls the AG í $\omega$ (to go) due to "the procession or motion of the sun" (VALPY, 1828, p. 194), maintaining thus a solar symbolism as the mano cornuta.

The imitation of the cow/bull appears in the LIBRAS BOBAGEM (foolishness), which etymologically corresponds to the ASL ANTAGONISTIC that represents two horned animals fighting (Figure 4). This meaning of silliness is also shown in certain ASL and LIBRAS signs that originate from the mano cornuta. For example, the LIBRAS IDIOTA (idiot) is cognate to the ASL FOOLISH/SILLY (VALLI, 2005, p. 178) and hence, to the LSF IDIOT, which originates from the mano cornuta (SHAW \& DELAPORTE, 2015, p. 247) (Figure 5). 


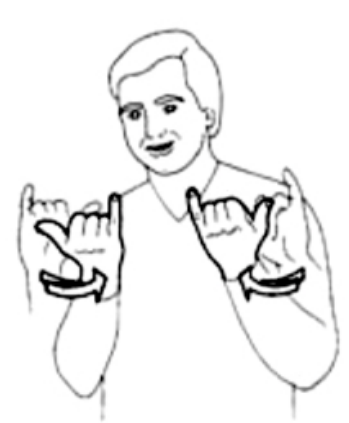

LSF S'AMUSER/ JOUER

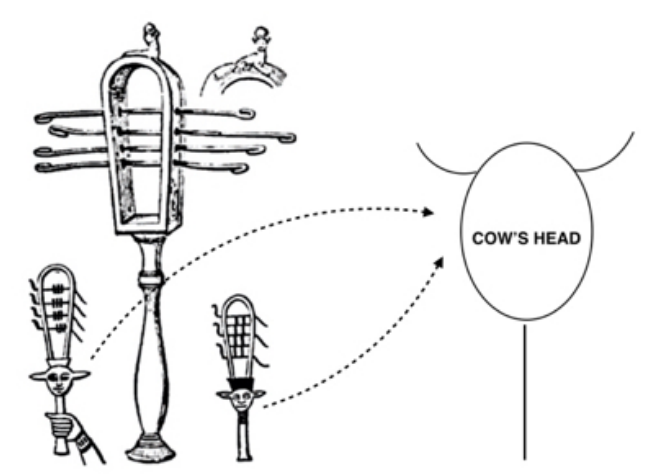

$\begin{array}{ll}\text { a. image selection } & \text { b. schematisation }\end{array}$

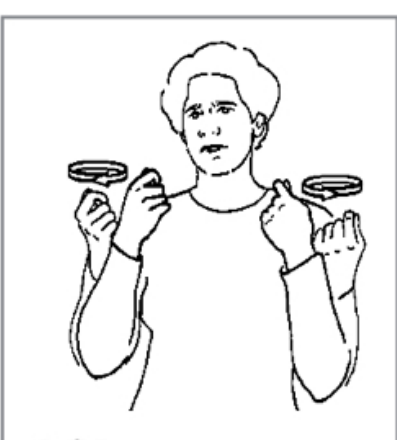

ASL CELEBRATE

(Shaw \& Delaporte, 2015, p. 40, 203)

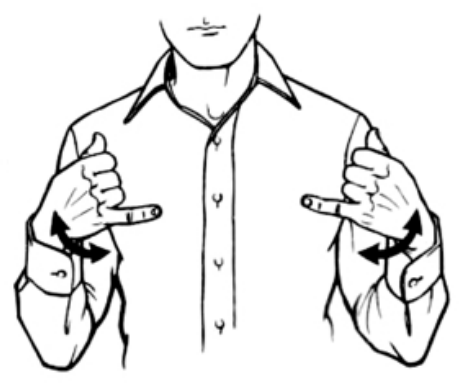

ASL PLAY

(Butterworth \& Flodin, 1983, p. 288)

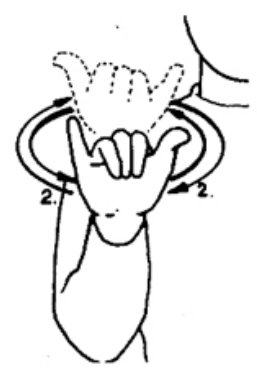

GSL PLAY

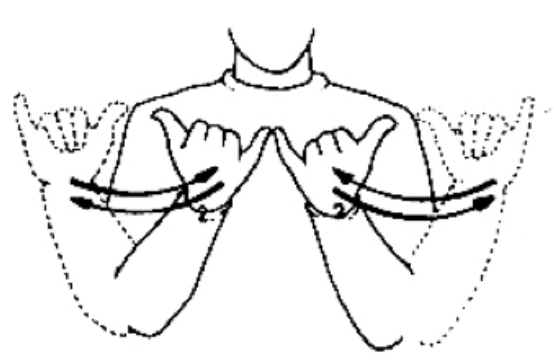

GSL WALK/ENTERTAINMENT

(Triantafyllides, 1991, p. 103)

Figure 3: ASL, GSL, and LIBRAS PLAY etymology.

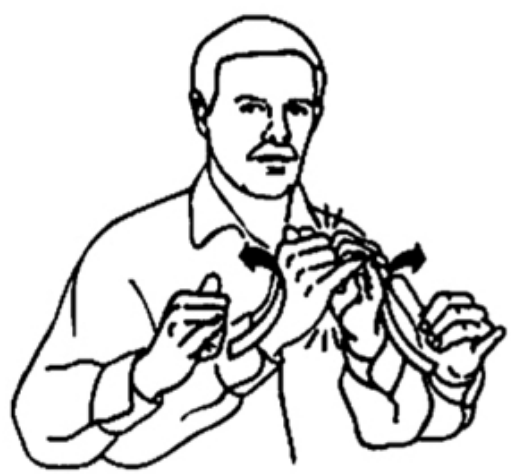

ASL ANTAGONISTIC

(Costello, 2008, p. 111)

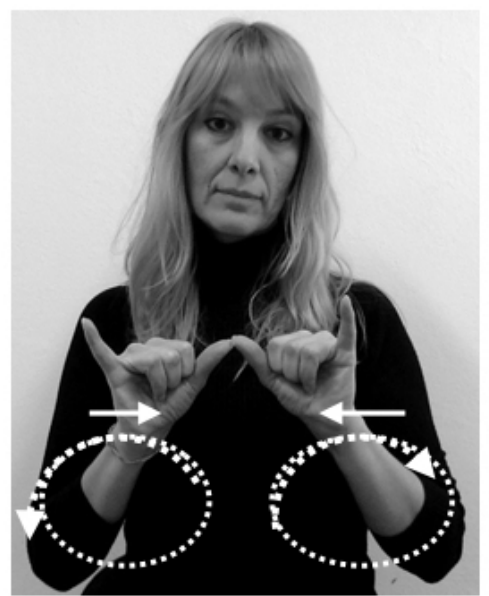

LIBRAS BOBAGEM

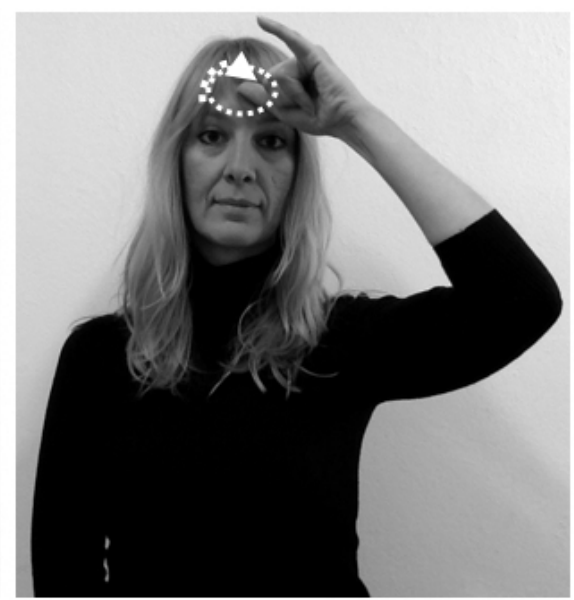

LIBRAS IDIOTA

Figure $4^{7}$ : The etymology of LIBRAS BOBAGEM and IDIOTA on mano cornuta.

Moreover, the LIBRAS signs AZAR (bad luck) and ENGANAR (to cheat) are also etymologically based on the mano cornuta (Figure 6). Firstly, the sign AZAR corresponds to the ASL wrONG, and the sign ENGANAR to the ASL DECEIVE ${ }_{2}$ (cf. also

\footnotetext{
to mano cornuta. The LIBRAS iDIOTA represents the horn on the forehead (see also Figure 6).
} 


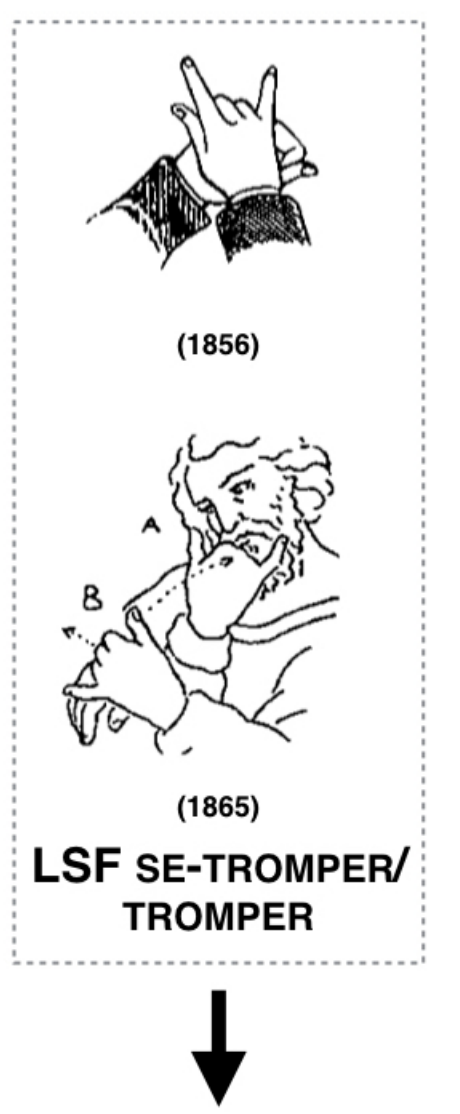

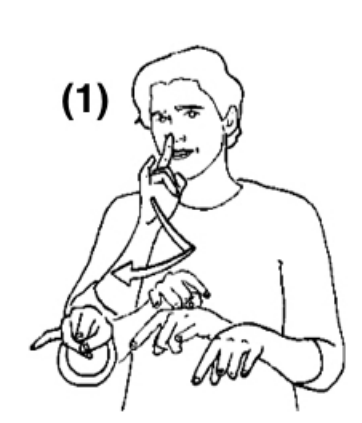

ASL DECEIVE 1

(3)

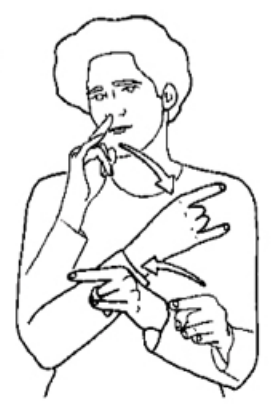

ASL IRONIC

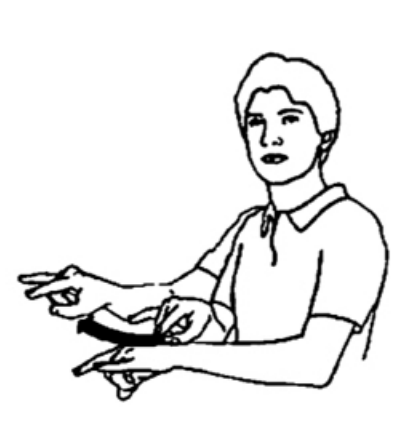

ASL DECEIVE2

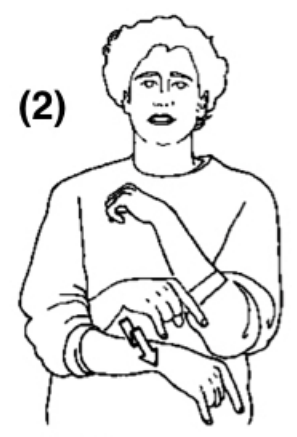

ASL CHEAT

(Shaw \& Delaporte, 2015, p. 43, 65, 66, 147, 175, 318)

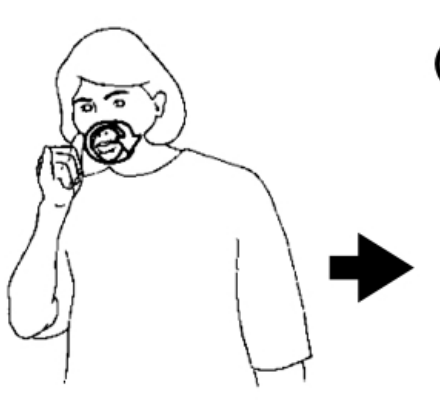

LSF IDIOT

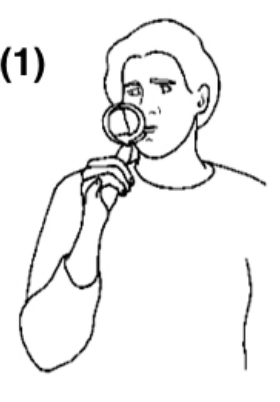

ASL SILLY

(Shaw \& Delaporte, 2015, p. 247)

(5)

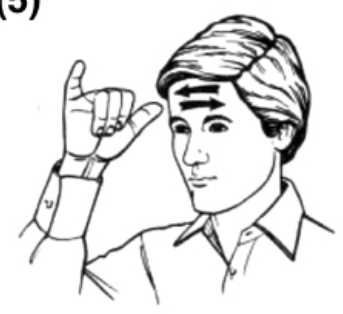

(4)

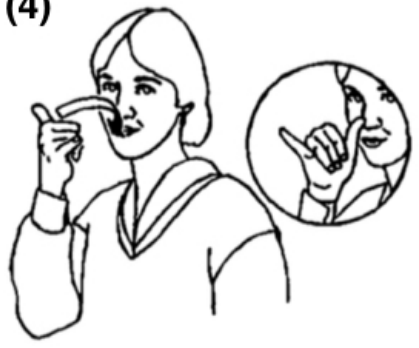

ASL SILLY 5

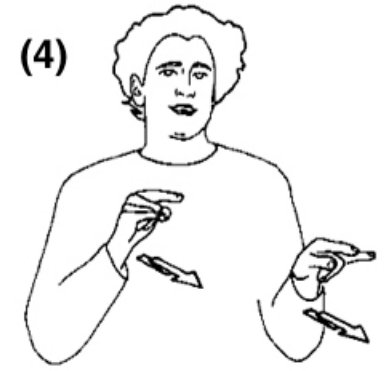

ASL MOCK

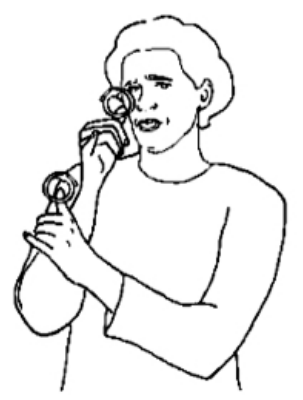

ASL SILLY,

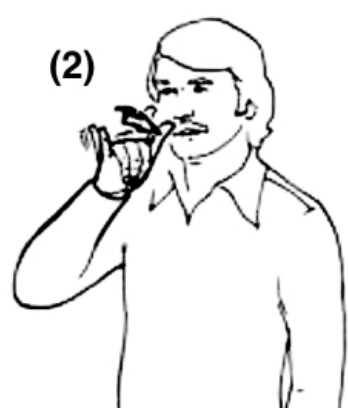

ASL SILLY $_{3}$

(Humphries et al., 1981, p. 201)

ASL FOOLISH/SILLY 6

(Costello, 2008, p. 455) (Tennant \& Gluszak Brown, 1998, p. 114) 
ASL MOCK and IRONIC) (p. 147, 175). Then, both signs (WRONG, DECEIVE ${ }_{2}$ ) originate from the LSF TROMPER/SE-TROMPER, which is etymologised on the mano cornuta. It appears that the original H-handshape changed to the Y-handshape (for AZAR), a modification that proves the alternate function of these two handshapes.

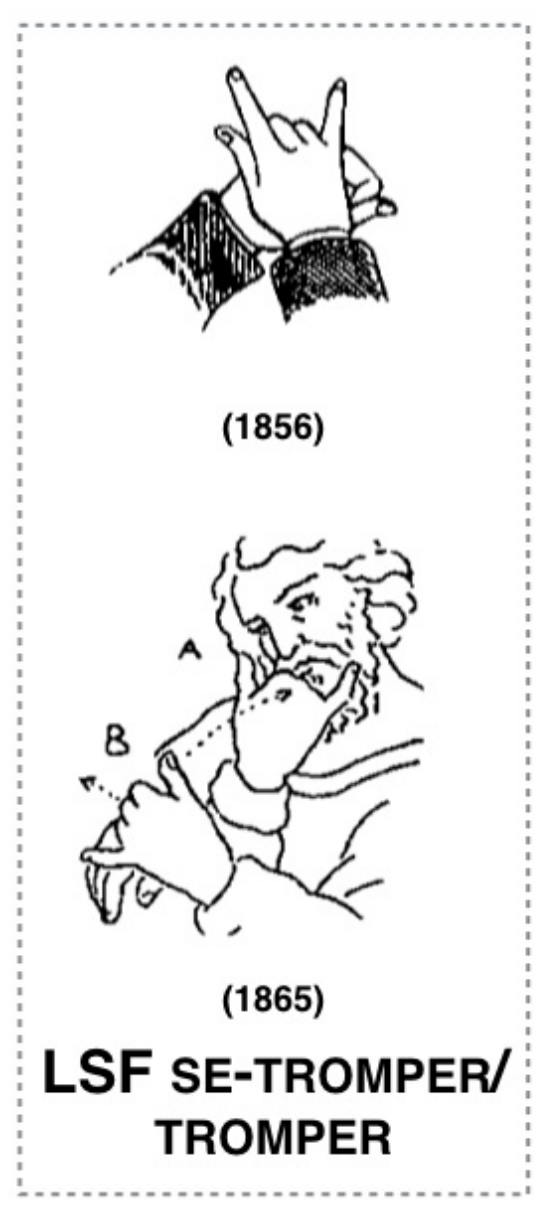

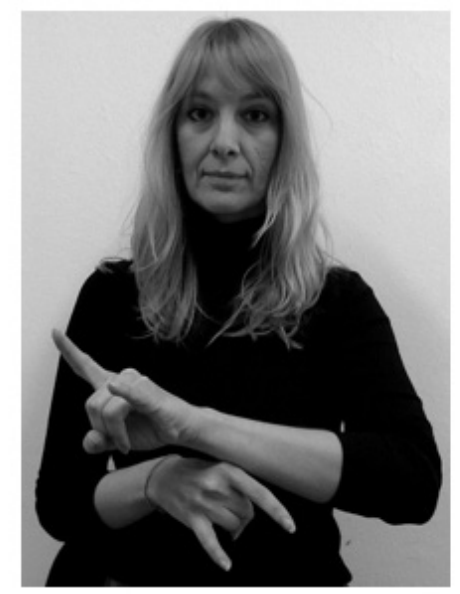
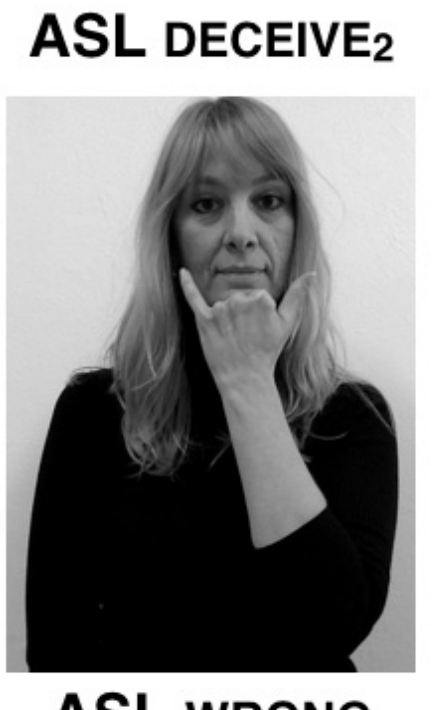

ASL WRONG

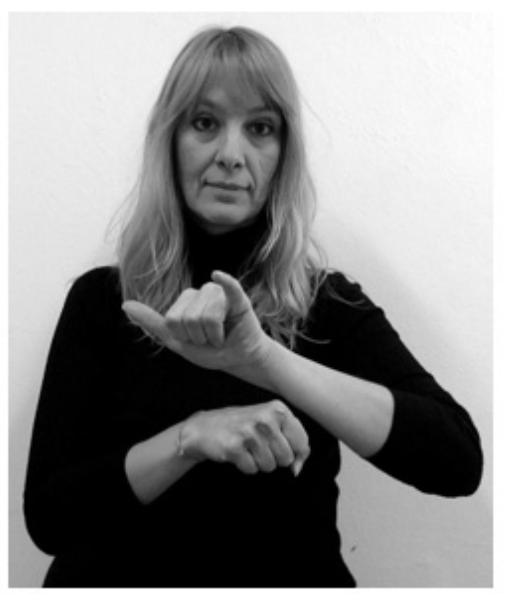

LIBRAS ENGANAR

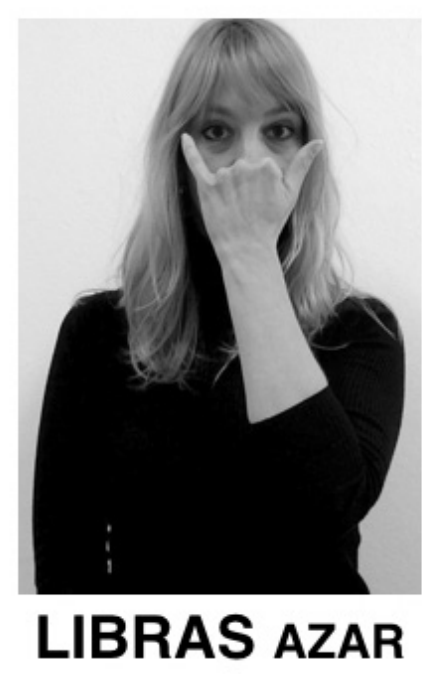

Figure 6: ASL WRONG and LIBRAS ENGANAR based on the LSF SE-TROMPER/TROMPER.

ASL and GSL converge in the colours YELLOW, BEIGE, BLUE, and BLOND (Figure 7). These, considering the spectrum of light, remind the sun symbolism of the mano cornuta as they refer to the colours of the daylight. Even if a lexicilised etymology is accepted for the sign YELLOW where the Y-hanshape represents the initial Y of the French jaune (yellow) (SHAW \& DELAPORTE, 2015, p. 117, 319), its articulation does not explain BLUE. However, a careful look at these signs shows their correspondence to PLAY, and, following its etymology, the sun symbolism of the mano cornuta appears again, for the

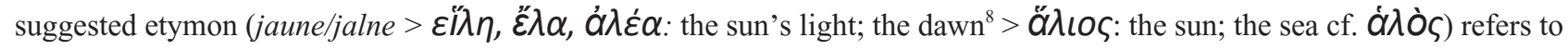
both colours, yellow and blue. In the ASL GOLD, the Y-handshape clearly represents a flickering gleam (Figure 8), which is repeated in the signs YELLOW and BLUE.

Although LIBRAS and GSL are not cognate SLs as LIBRAS and ASL are, they correspond to the signs CAPITAL and CENTRE/ATHENS 2 (Figure 9). In GSL, these signs also denote ATHENS and CITY, meanings that connect to the mano cornuta as it

8 Cf. for dawn: áw 
relates to the axis of the earth (see vase no. 131). Since the sign refers to Athens and hence, to the goddess Athena from whom the city is named, the mano cornuta refers to the Panathenaia celebrations on the month $\dot{\varepsilon} K \check{\alpha} \tau O \mu B \alpha \iota \omega \dot{v}$ (Hecatombaeon), during which the constellation Ophis (current Draco) rotated around the north pole, the axis of the earth (BOUTSIKAS, 2011, p. 307). This midpoint of the pole is represented by the Y-handshape and/or the $\mathrm{A}^{\circ}$-handshape in the middle of the palm. This second handshape strongly demonstrates this relationship since it is attested by the goddess Athena in front of Heracles (BOARDMAN, 1974, p. 118), who also performs the mano cornuta in vase no. 131. Interestingly, the Y-handshape means the 'centre' in the SL of Italy (SPREADTHESIGN, 2012), where the mano cornuta still exists.

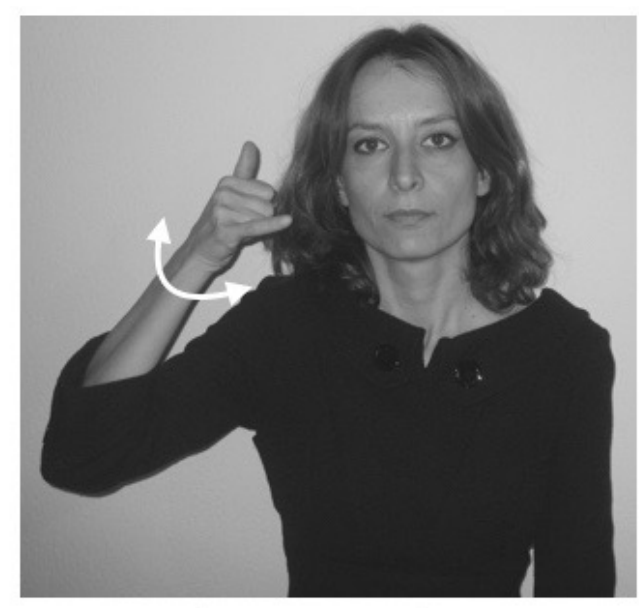

ASL: YELLOW $\mathbf{W}_{\mathbf{2}}$

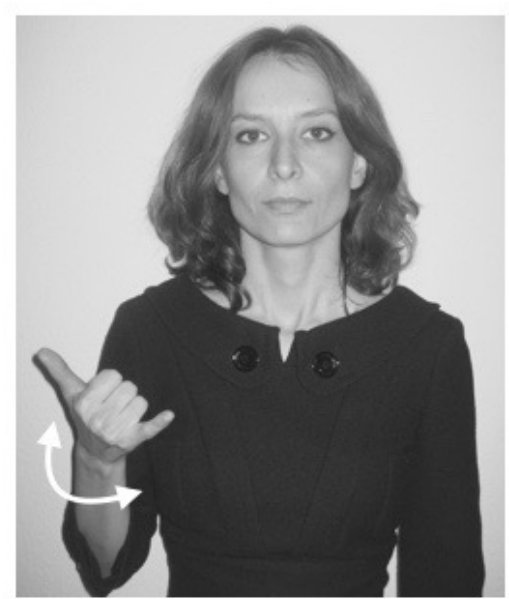

ASL: YELLOW 1 GSL: BLUE

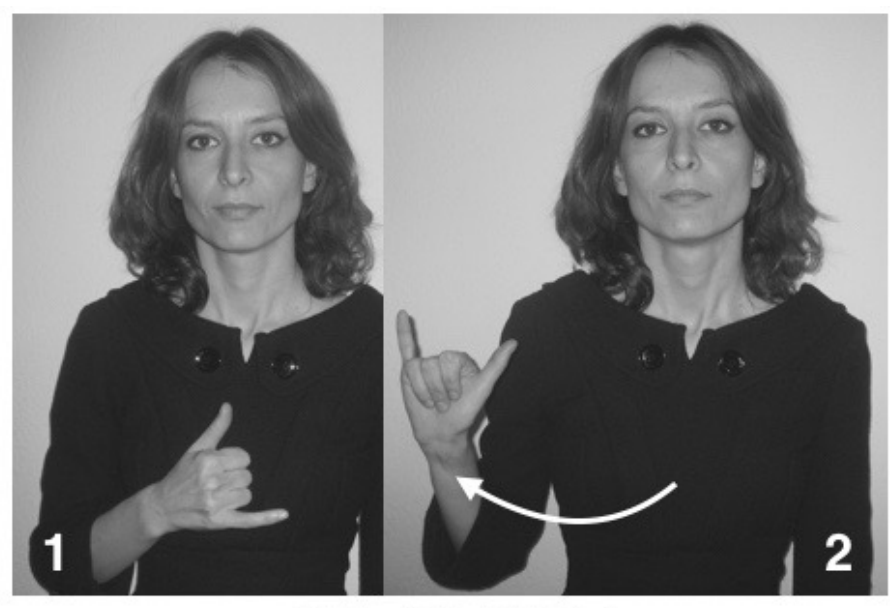

ASL: BLONDE

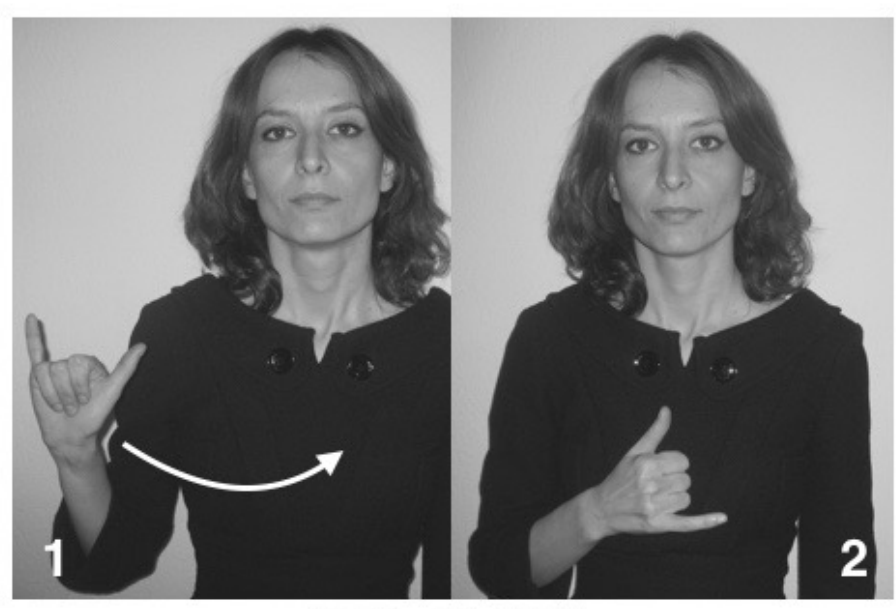

GSL: BEIGE

Figure 7: ASL and GSL colour convergence.

\section{DISCUSSION}

The mano cornuta is found to associate with an ancient solar and fertility symbolism, which, subsequently, is fossilised in modern SLs, like GSL and ASL under the meanings of colours and play. This convergence can be explained by the diffusion of the ancient worship of the Mother Goddess, which, across civilisations, referred to the agricultural cycle for planting and harvesting. In this cycle, the conjunction of the sun and moon (the full moon) used to take place once every eight years during the summer solstice, during which, at least initially, the Olympics were celebrated, as well as the new year. With this specific conjunction and time of the year the mano cornuta appears to associate as the iconography of vase no. 131 depicts, 
as well as its performance by solar gods (e.g. Zeus, Dionysus, Apollo, Heracles).

(1)

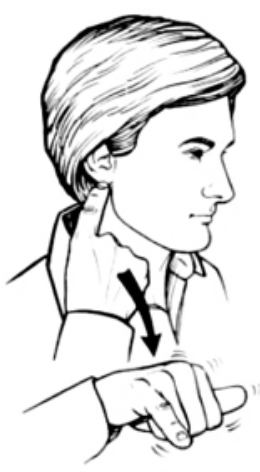

(2)

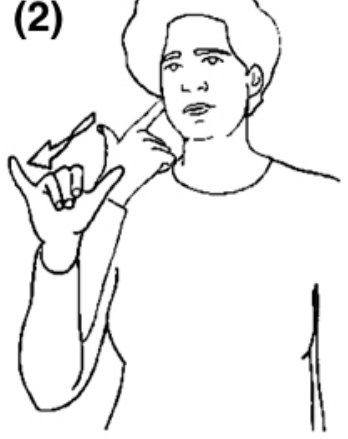

ASL GOLD/CALIFORNIA

(1) Butterworth \& Flodin, 1995, p. 197; (2) Shaw \& Delaporte, 2015, p. 117; (3) Humphries, Padden, O'Rourke, 1981, p. 93
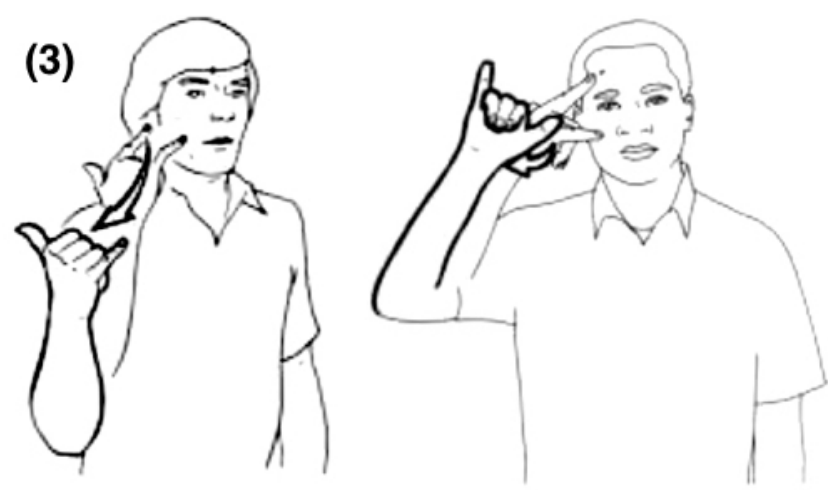

ASL BLOND

(Valli, 2005, p. 51)

Figure 8: The ASL GOLD and BLOND.

The summer solstice was used to measure the shortest noon shadow that defined the north pole, and hence, the earth's and celestial axis (ISLER, 1989; 1991). In fact, the bull's horns were used as a gnomon for this measurement (ISLER, 1991). The iconography of the vase no. 131 relates the mano cornuta to the pole of the earth, putting the swan (as the swan constellation) over the omphalus (the axis of the earth), and to Heracles, who initiated the Olympics. The athletes in this vase also recall these games, which were honoring the Mother Goddess $\Gamma \alpha \tilde{\alpha} \alpha$ in her sanctuary in Olympia, and Zeus as her triumphant son (ROBERTSON, 2010, p. 69). Moreover, the summer solstice was fixed for the celebration of the Olympics (HAN$\mathrm{NAH}, 2009$, p. 48). In particular, they used to start at the full moon of the summer solstice, during which the heliacal rising of Sirius was also taking place (RICHER, 1994, p. 111, 119), marking the beginning of the year. In fact, the new year in Athens commenced on the first of Hekatombaion (the month of Panathenaia), on the first new moon, the sickle moon (BILIC $\square, 2012$, p. 514; HANNAH, 2009, p. 36) that the mano cornuta represented.

This north passage of the sun defined the agricultural period from May first to middle August (ca. 105 days), which involved the epagomenal ${ }^{9}$ days of the ancient calendars. In particular, the fourth epagomenal day was traditionally the day of the Mother Goddess (SALEM, 1937, p. 166), which was also equated to the heliacal rising of Sirius (HOLBERG, 2007, p. 4; WELLS, 1985, p. 258-259). Initially, then, her celebrations occurred when the conjunction of the sun and the full moon aligned ${ }^{10}$ perfectly with Sirius (MAGLI, 2016, p. 70-71). However, this planetary conjunction started occurring days after the summer solstice due to the precession of the equinoxes (cf. WELLS, 1985, p. 279, 291).

As a result, the mother was celebrated at the beginning of August in $\lambda \cup \chi v о \kappa \alpha i ̈ \alpha$ (the Feast of Lanterns), when the sun enters in the centre of the constellation Cancer (HANNAH, 2009, p. 17; RICHER, 1994, p. 122). This central placement represented in antiquity the impregnation of the seed (by the sun) in the womb of the Mother (BUSENBARK, 1949, p. 133),

\footnotetext{
9 The intercalation of an extra month was thrice every eight years. The first of Hekatombaion and the solstice "will have varied at different moments within the cycle of intercalation: Hekatombaion 1 could fall at different points within a span of slightly more than twenty days in the Julian solar calendar" (PARKER, 2005, p. 193).

10 Such alignment occurred in the summer solstice in 1956 BCE (WELLS, 1985, p. 288).
} 
and the conception of $\operatorname{god}^{11}$ (ESTRADA-BELLI, 2006, p. 63), a representation that recalls the sun as Horus ${ }^{12}$ performing the mano cornuta in the centre of ouroboros. In turn, the serpent reminds of Ophis and the centre of the earth as seen during the Panathenaea on Hecatombaeon 27, a date that coincides with the Mother's day. In fact, the hundredth day of the 105-day cycle was her day, when the lower conjunction of Venus also conjoined, passing between the earth and the sun. Five days before this conjunction, Venus appears as a thin crescent, which the mano cornuta also represented. This relationship is reminiscent in the GSL THURSDAY, which represents an ancient form of the number five (TRIANTAFYLLIDES, 1990, p. 101), her number.

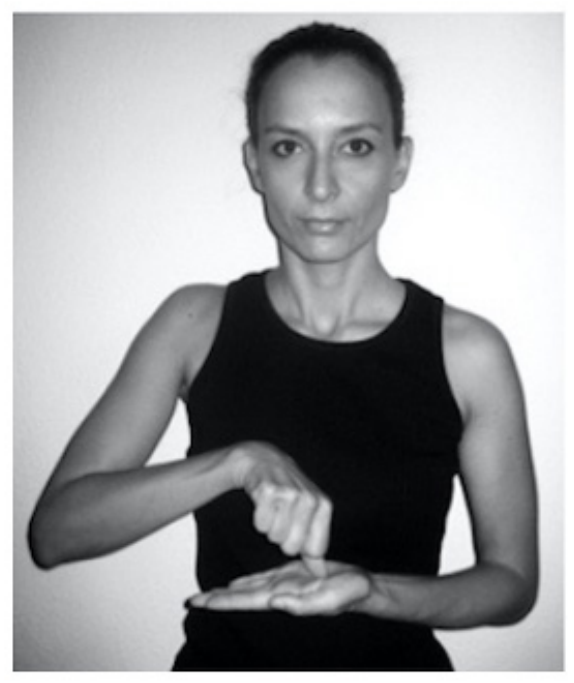

GSL ATHENS 1

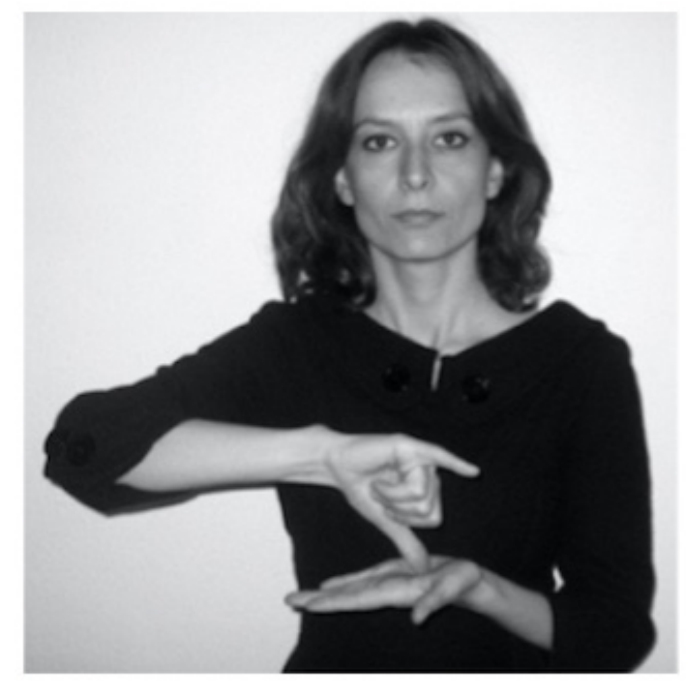

GSL ATHENS 2

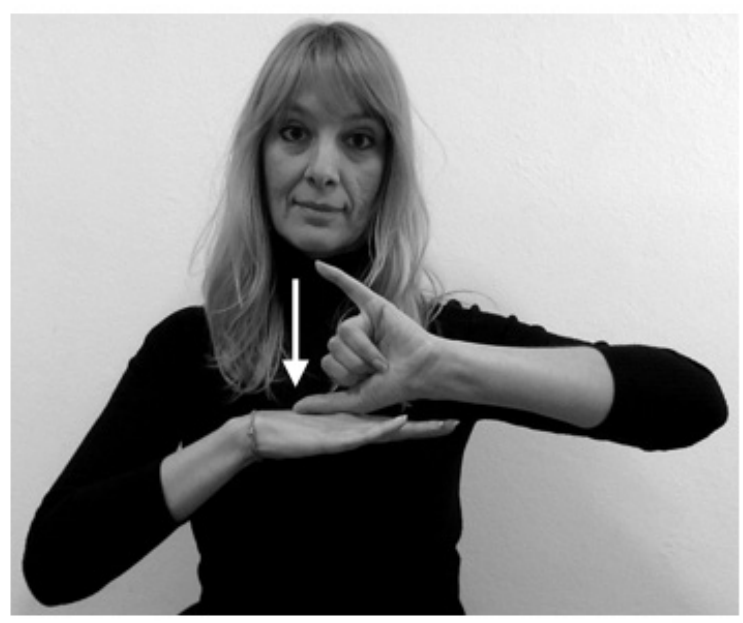

\section{LIBRAS CAPITAL}

Figure 9: GSL and LIBRAS sign convergence CAPITAL and CENTRE.

Based on this planetary alignment, the mano cornuta etymologises the GSL ETERNITY and ASL FOREVER. As Sirius was equated to the Mother, the mano cornuta also referred to its return cycle (every 1461 years) on the first day of the new year (HOLBERG, 2007, p. 4) known as the $\alpha i \dot{\omega} v$ that meant eternity and lifetime, a meaning found in Venus too (cf. $\alpha u ̈ \omega \varsigma$,

11 The classical authors mention the calf Apis/Epaphus born of a cow that is made pregnant by a light from heaven (FAULKNER, 1968, p. 44).

12 In 432 BCE, the summer solstice fell on Skirophorion 13 (BILIC $\square, 2012$, p. 516; HANNAH, 2009, p. 36), in which a sacrifice to Zeus

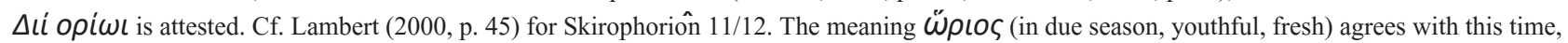
since Skirophorion as the last month of the Attic calendar, announced the new year on the first of Hekatombaion. Cf. also $\tilde{\omega} \rho \circ \zeta$, year. 
life). Especially the ASL FOREVER is articulated by the sign ALWAYs (BUTTERWORTH, ROD \& FLODIN, 1983, p. 166) and the Y-handshape extending from the middle of the forehead. Shaw and Delaporte $(2015$, p. 106) base its etymology on the LSF JUSQU'A (until), arguing the Y-handshape to represent the $<\mathrm{J}>$ letter of the word. Interestingly, its etymon (jusqu'à $>$ Latin usquĕ< adv. us-, all the way, continuously, constantly) leads to the AG $\tilde{U} \zeta$ (whither, as far as) and $\tilde{U} \zeta / \tilde{U} \varsigma$ (mother), from

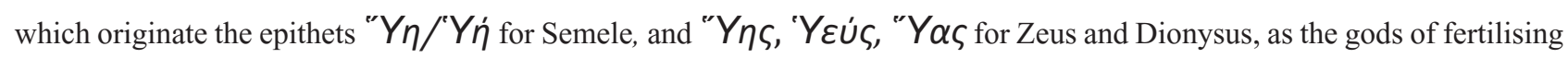
moisture (cf. also Ü $\omega$, to rain). Hence, the handshape again links to solar and fertility meanings. Additionally, in other European SLs 'forever' (e.g. Polish ZAWSZE; Austria FÜR-IMMER; Czech NAVŽDY) is performed by the Y-handshape and a cyclical movement alike the one of the ASL ALWAYS, which are not cognate to ASL. Additionally, the etymologies of their 'forever' words refer to the earth (zawsze $>\gamma \tilde{\alpha}, \kappa \alpha \dot{\alpha}$ : earth), the daylight (immer $>\tilde{\alpha} \mu \alpha \rho, \dot{\eta} \mu \varepsilon \dot{\varepsilon} \rho$ : day) and the axis as the navel of the earth (navždy > vōós, $v \alpha \tilde{U} \varsigma$ : temple, portable shrine, ship).

Furthermore, the mano cornuta is found to be performed more often with the right hand, which in some cultures symbolised the rain season and the day sky, whereas the left hand, the dry season and the night (MILBRATH, 1999, p. 14). Due to its relation to the day and sun, the right hand designated masculinity, whereas the left, femininity and the moon (PALKA, 2002, p. 422). This symbolism agrees with this present iconography of the mano cornuta, and with the planetary alignment of the Mother's worship. Such masculine and phallic connotations are found in the LSF etymologies (e.g. ASL DECEIVE), and in the non-cognate LIBRAS sign ADULTERY. In these signs, the mano cornuta was regarded to replacing the phallus that had apotropaic power (BERRY, 1968; LYKIARDOPOULOS, 1981).

Moreover, all three SLs form metonymically signs that mean countries, such as ITALY in LIBRAS due to the present use of the mano cornuta; SPAIN in GSL, because of the bullfighting in the country; and NETHERLANDS in ASL because of the country's large cattle farming and industry. Additionally, in LIBRAS, the sign FARM means the place for rearing animals including cattle, and in GSL, the signs MAMMAL (as animal classification) and ANIMALS.

\section{CONCLUSION}

The study examined the symbolism of the mano cornuta in Attic vase iconography, which, subsequently, extended into specific/intra-cultural meanings through juxtapositions of elements and parallelisms, so as to etymologise certain signs of three modern SLs. So far, this investigation proves the mano cornuta to be the etymon of signs that associate with meanings of light, adultery, foolishness, centrality, and eternity. Since it is shown to be performed in the ancient summer solstice celebrations, when the Mother Goddess worship was also taking place, its fertility meaning - and by extension its phallic one - is justified by the sun's symbolic power (at its farthest point northward) to fertilise the earth under the moisture of the full moon. 


\section{REFERENCES}

ANDREWS, L. A dictionary of the Hawaiian language. Honolulu, Hawaii: The Board of Commissioners of Public Archives of the Territory of Hawaii, 1922.

AZAMBUJA LIRA de, G.; SOUZA de, T.A.F. Dicionário da Lingua Brasileira de Sinais V3. Acessibilidade Brasil, 2011. Available at: <http://www.acessibilidadebrasil.org.br/libras_3/>.

BALDACCHINO, J. The Evil Eye (ghajn) in Malta: Grappling with Skinner's pigeons and rehabilitating lame ducks. The Australian Journal of Anthropology, v. 21, p. 188-207, 2010.

BERRY, V. Neapolitan charms against the evil eye. Folklore, n.4, v.79, p. 250-256, 1968.

BIEDERMANN, H. Dictionary of symbolism. Cultural icons and the meanings behind them. New York: Facts On File, 1989.

BIEUNDURRY, Clifton. Traditional hand signs (Australia). Filmed by K. David Harrison, Enduring Voices Project, 2007: $<\mathrm{https}: / /$ www.youtube.com/watch? $\mathrm{v}=\mathrm{qLwf} 2 \mathrm{~b} 4 \mathrm{kWKo}>$.

BILIC,T. Apollo, Helios, and the solstices in the Athenian, Delphian, and Delian calendars. Numen, v. 59, p.509-532, 2012. BOARDMAN, J. Athenian black figure vases. London: Thames and Hudson, 1974.

BOUTSIKAS, E. Astronomical evidence for the timing of the Panathenaia. American Journal of Archaeology, n. 2, v. 115, p. 303-309, 2011.

BUSENBARK, E. Symbols, sex and the stars in popular beliefs. New York: Truth Seeker Company Inc, 1949.

BUTTERWORTH, Rod R.; FLODIN, Mickey. The Perigee visual dictionary of signing: An A to Z guide to over 1,200 signs of American sign language. New York: Putnam, 1983 (1st edition); 1995 (2nd edition).

CARroll, C.; CARroll, R. Mudras of India. A comprehensive guide to the hand gestures of yoga and Indian dance. London: Singing Dragon, 2013.

COHEN, M.E. The cultic calendars of the ancient near East. Bethesda, Maryland: CDL Press, 1993.

CORPUS VASORUM ANTIQUORUM. University of Oxford, 2014: <http://www.cvaonline.org/cva/>.

COSTELLO, E. American Sign Language dictionary. New York, NY: Random House, 2008.

DI GIULIO, A.M. The frame drum as a dionysian symbol in scenes on Apulian pottery. RIdIM/RCMI Newsletter, n. 1, v. 16, p. 2-7, 1991.

EDUCATIONAL POLICY INSTITUTE. Online Dictionary of Concepts in GSL. Athens, Greece: National Strategic Reference Framework ESPA 2007-2013, Operational Programme “Education and Lifelong Learning,” 2013. Available at: $<$ http://prosvasimo.gr/el/onlne-lexiko-ennoiwn>.

ELWORTHY, F.T. Horns of honour and other studies in the by-ways of archaeology. London: John Murray, 1900.

ESTRADA-BELLI, Francisco. Lightning sky, rain, and the maize god: The ideology of preclassic Maya rulers at Cival, Peten, Guatemala. Ancient Mesoamerica, n. 1, v. 17, p. 57 - 78, 2006.

FAULKNER, R. O. The Pregnancy of Isis. The Journal of Egyptian Archaeology, v. 54, p. 40-44, 1968.

GRAUliCH, M.; CARRASCO, P.; COE, M.D.; DURAND-FOREST, J.; DE GALINIER, J.; GONZAøLEZ, Y., et al. The metaphor of the day in ancient Mexican myth and ritual. Current Anthropology, n. 1, v. 22, p. 45-60, 1981.

GREEN, H.H. Cosmic order at Chocolá: implications of solar observations of the eastern horizon at Chocolá, Suchitepéquez, Guatemala. In: ALDANA Y VILLALOBOS, G. \& BARNHART, E.L. (Eds.) Archaeoastronomy and the Maya. Oxford: Oxbow Books, 2014, p. 17 - 39.

GUBERNATIS, A. Zoological mythology or the legends of animals. Vol. I. London: Trubner \& Co, 1872.

MERTZANI, Maria The ancient and modern mano cornuta use. In: Cadernos do Lepaarq, v. XV, n.30., p. 19-37, Jul-Dez. 2018. 
HANNAH, R. Time in antiquity. London: Routledge, 2009.

HARRISON, J.E. Prolegomena to the study of Greek religion. Cambridge: The University press, 1908.

HEALEY, T. The symbolism of the cross in sacred and secular art. Leonardo, n. 4, v. 10, p. 289-294, 1977.

HOLBERG, J.B. Sirius: Brightest diamond in the night sky. New York: Springer-Verlag, 2007.

HOLLOWAY, R.R. The bulls in the "Tomb of the Bulls" at Tarquinia. American Journal of Archaeology, n. 4, v. 90, p. 447$452,1986$.

HUMPHRIES, Tom; PADDEN, Carol; O’ROURKE, Terrence J. A basic course in American sign language. Silver Spring, Md.: T.J. Publishers, 1981.

ISLER, Martin. An Ancient Method of Finding and Extending Direction. Journal of the American Research Center in Egypt, v. 26, p. 191-206, 1989.

ISLER, Martin. The gnomon in Egyptian antiquity. Journal of the American Research Center in Egypt, v. 28, p. 155-185. 1991.

KING, W.S. Hand gestures. Western Folklore, n. 3, v. 8, p. 263-264, 1949.

KOOIJ, E. van der; CRASBORN, O.A. Chapter 11: Phonology. In: BAKER, A.; BOGAERTE, B. van den; PFAU, R.; SCHERMER, T. (Eds.) The Linguistics of Sign Languages: An introduction. Amsterdam: John Benjamins, 2016, p. $251-278$

KRIPPNER, S.; BUDDEN, A.; GALLANTE, R.; BOVA, M. The indigenous healing tradition in Calabria, Italy. International Journal of Transpersonal Studies, n.1-2, v. 30, p. 48-62, 2011.

LAMBERT, Stephen D. The sacrificial calendar of the Marathonian Tetrapolis: A Revised Text. Zeitschrift für Papyrologie und Epigraphik, Bd. 130, p. 43-70, 2000.

LOGIADIS, N.; LOGIADI, M.N. Dictionary of sign language. $\Lambda \varepsilon \xi \iota k o ́ ~ v o \eta \mu \alpha \tau \iota k n ́ \varsigma ~ \gamma \lambda \omega ́ \sigma \sigma \alpha \varsigma$ (in Greek). Athens: Potamitis Press, 1985

LYKIARDOPOULOS, A. The evil eye: Towards an exhaustive study. Folklore, n. 2, v. 92, p. 221-230, 1981.

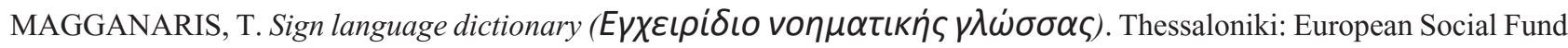
"Employment - HORIZON" \& Aristotle University of Thessaloniki, 1998.

MACGILliVRAY, A. The astral labyrinth at Knossos. British School at Athens Studies, Knossos: Palace, City, State, v. 12 , p. $329-338,2004$.

MAGINI, L. Stars, myths and rituals in Etruscan Rome. New York, NY: Springer, 2015.

MAGLI, Giulio. Mysteries and Discoveries of Archaeoastronomy. From Giza to Easter Island. New York, NY: Praxis Publishing Ltd, 2009.

MAGLI, Giulio. Archaeoastronomy: Introduction to the Science of Stars and Stones. Springer: Springer International Publishing Switzerland, 2016

MERTZANI, M. Iconicity in ancient languages. A case study of KA-RA in Greek. Cadernos do LEPAARQ, n. 27, v. 14, p. 72-88, 2017

MILBRATH, S. Star gods of the Maya. Astronomy in art, folklore, and calendars. Austin, TX: University of Texas Press, 1999.

MORRIS, Desmond. Bodytalk: The meaning of human gestures. New York: Crown Trade Paperbacks, 1994.

MORRIS, Desmond. Gestures, their origins and distribution. New York: Stein and Day, 1979. 
MOUNTFORD, P.C. Gesture language of the Ngada tribe of the Warburton Ranges, western Australia. Oceania, n. 2, v. 9, p. $152-155,1938$.

PALKA, J.W. Left/right symbolism and the body in ancient Maya iconography and culture. Latin American Antiquity, n. 4, v. 13, p. 419-443, 2002.

PANAITE, E. To raise one's forefinger towards the king: A Libyan-related gesture? Poster presented at the Annual General Meeting and Scholars' Colloquium "Masterpieces of Ancient Egyptian Art", The Society for the Study of Egyptian Antiquities Symposium, November, 4-6, 2014: <https://www.academia.edu/18875602/_To_raise_one_s_forefinger_towards_the_king_a_Libyan-related_gesture_poster_presented_to_the_SSEA_AGM_Nov_2014>.

PARKER, Robert. Polytheism and society at Athens. Oxford: Oxford University Press, 2005.

PARKHURST, Stephen; PARKHURST, Dianne. Lexical comparisons of signed languages and the effects of iconicity. Work Papers of the Summer Institute of Linguistics, University of North Dakota Session, vol. 47, 2003.

PUKUI, Mary Kawena; ELBERT, Samuel Hoyt; MOOKINI, Esther T. New pocket Hawaiian dictionary : with a concise grammar and given names in Hawaiian. Honolulu: University of Hawaii Press, 1992.

RICHER, Jean. Sacred geography of the ancient Greeks. Astrological Symbolism in Art, Architecture and Landscape. Albany: State University of New York Press, 1994.

ROBERTSON, N. Religion and reconciliation in Greek Cities. The sacred laws of Selinus and Cyrene. Oxford: Oxford University Press, 2010.

ROTH, A.M. Fingers, stars, and the 'opening of the mouth': The nature and function of the ntrwj-. The Journal of Egyptian Archaeology, v. 79, p. 57-79, 1993.

ROSSOTTI, H. Fire: servant, scourge and enigma. Mineola, New York: Dover Publications, Inc, 2002.

SALE, J.R. Protecting fertility in Fra Filippo Lippi's portrait of a woman with a man at a casement. Metropolitan Museum Journal, v. 51, p. 65-83, 2016.

SALEM, M. S. The 'Lychnapsia Philocaliana' and the Birthday of Isis. The Journal of Roman Studies, v. 27(2), p. 165-167, 1937.

SHAW, E.; DELAPORTE, Y. A historical and etymological dictionary of American Sign Language. Washington, DC: Gallaudet University Press, 2015.

SIMPSON, W.K. The mastabas of Qar and Idu G 7101 and 7102. Boston: Department of Egyptian and Ancient Near Eastern Art, Museum of Fine Arts, 1976.

ŠPRAJC, I. Venus-Rain-Maize Complex in the Mesoamerican world view II. Archaeoastronomy, v.18, p.27-53, 1993.

SPREADTHESIGN. Örebro, Sweden: European Sign Language Centre, 2012: < www.spreadthesign.com>.

TENNANT, R.A.; GLUSZAK BROWN, M. The American Sign Language handshape dictionary. Washington, D.C.: Gallaudet University Press, 1998.

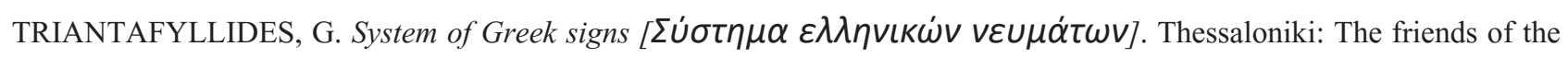
Deaf in Thessaloniki Club, 1990.

VALLI, Clayton. The Gallaudet dictionary of American Sign Language. Washington, D.C.: Gallaudet University Press, 2005.

VALPY, F.E.J. An etymological dictionary of the Latin language. London: Printed by A.J. Valpy, sold by Baldwin and Co, 1828.

WELLS, R. A. Sothis and the Satet Temple on Elephantine: A Direct connection. Studien zur Altäyptischen Kultur, Bd. 12, p. $255-302,1985$. 
WILLIAMS, D. The cultural appropriation of dances and ceremonies. Visual Anthropology, n. 4, v. 13, p.345-362, 2000. WILKINSON, J.G. The ancient Egyptians. Their life and customs. Volume one. London: Senate, 1994.

Recebido em: 30/06/2018

Aprovado em: 06/08/2018

Publicado em: 30/11/2018 